\title{
Population Restructuring: The Impact on Poverty Eradication in Malaysia and Medina
}

\author{
Radieah Mohd Nor, Sharifah Nurlaili Farhana Syed Azhar, Kamarulazizi Ibrahim \\ Centre for Global Sustainability Studies (CGSS), Universiti Sains Malaysia, Penang, Malaysia \\ Email: radieah@usm.my, sh.nurlaili@usm.my, kamarul@usm.my
}

Received 5 March 2015; accepted 7 June 2015; published 10 June 2015

Copyright $@ 2015$ by authors and Scientific Research Publishing Inc.

This work is licensed under the Creative Commons Attribution International License (CC BY). http://creativecommons.org/licenses/by/4.0/

(c) (i) Open Access

\begin{abstract}
Before the restructuring, Medina's residents live in hostile environment and constantly waging war between themselves. In Malaysia, population's restructuring occurred as the result of May 13, 1969's tragedies, which became a black spot in the history of Malaysia. Through population's restructuring, the poverty rates in Medina and Malaysia decrease. There are five key elements that are kept in the population's restructuring in Medina and Malaysia. These elements are religion, life, intellect, lineage and property. These five elements are contained in Maqasid Shariyah.
\end{abstract}

\section{Keywords}

Restructuring of Population, Poverty, Malaysia, Medina, May 13, Maqasid Shariyah

\section{Introduction}

The progress of one's country will not develop without the existence of an understanding among its nation. This situation can be seen throughout the history of Medina and Malaysia. One of the socio-economic and political impacts that can be observed is during the time before the Hijri of the Prophet to Medina and during the May 13 race riots in the year 1969 in Malaysia. It is known as the May 13 as on that date a race riot has occurred in Malaysia, especially among the Malays and Chinese races. However, the Malaysia government then immediately formulates a policy in 1971 by presenting the New Economic Policy (NEP). Among other purposes, the establishment of the NEP is to restructure the population so that unity can be achieved and poverty can be reduced.

Race riots were not uncommon, as it had happened before the emigration of Prophet Muhammad to Medina. Race riot that occurred in a country can weaken the political system and cripple the country's economic system. It also indirectly affects the social system in the country. Such situation has led the Prophet Muhammad to bridge and unite the people in Medina after his emigration from Mecca in 622 AD equals to 1st Hijri year. Constant tribal feud in Medina has caused Rasulullah SAW to revise a strategy by building a mosque, introduce the 
concept of Muslim brotherhood and establish the Constitution of Medina [1].

\section{Population Restructuring: Medina}

The population restructuring in Medina occurred as soon as the Prophet Muhammad migrated from Mecca to Medina. The Prophet's migration to Medina was not to escape the persecution over the Muslims in Mecca. Instead, it is a command from God. Moreover, through the emigration, it becomes easier to spread Islam and to establish the Islamic civilization with Medina as it base [1].

The efforts to establish an Islamic state is not easy. The difficulty occurs when the unity between all groups, tribes and races in Medina was very fragile. When the Prophet arrived in Medina, he had to deal with three different groups. The three groups are;

1) The Prophet's Companions-They consist of people who migrated from Mecca to Medina, known as the Muhajirs and Muslims who already resides in Medina and had converted to Islam, known as Ansar.

2) The non-Muslims - They are residents of Medina who still have not embraced Islam after The Prophet arrives in Medina.

3) The Jewish population-They also represent the people of Medina.

\subsection{Community of Medina before the Arrival of Islam}

Before the immigration of the Prophet s.a.w, Medina was known as Yathrib. The city is the second most important city in Hejaz after Mecca. It is located $500 \mathrm{~km}$ to the north of Mecca. Medina is a lush valley and is located in the middle of trade routes between Syria in the north and Mecca in the south. Its location in the middle of trade routes makes the town became the most important city in various economic activities, particularly in the agricultural sector. Before the advent of Islam, more than half of the population of Medina are Jews, while the rest are Wathani, a religion that worship idols. Many of them descended from Aws and Khazraj. However, their close association with the Jews led to their better religious knowledge on the aspects of God and made it easier for them to embrace Islam compared to the Arab population in Mecca.

\subsubsection{The Aws and Khazraj}

The Aws and Khazraj, also known as Banu Qailah comes from the south of the Arabian Peninsula. They settled in Medina after the break of the Ma'rib Dam in Yemen. They dominate the agricultural sector so successfully that they have overrides the power of the Jews in Medina. The Jews did not enjoy the increasingly widespread influence of the Aws and Khazraj in Medina. The Jews then spread antagonisms between the Aws and Khazraj to weaken their power. The Khazraj has greater and more influence compared to the Aws. The member of their tribes has converts to Islam earlier and in greater numbers compared to the Aws. This situation occurs because many individuals from Aws have covenant with the Jews to counterbalance the power and influence of the Khazraj. The covenance between the Aws and the Jews was evidence during the Battle of Bu'ath. During the war, the Jewish that was in favor of Aws had sent over troops to fight against the Khazraj.

\subsubsection{The Jews}

The Jews were peoples that decended from Palestine who have fled to southern Palestine after evangelism by Prophet Isa a.s. Their mixing with Arabs resulted in the names of the Jewish's clans has similarities with the Arab’s such as Banu Muawiyah and Banu Tha'labah. There are about 20 Jewish clans in Medina. However, only three clans are famous and influential, which is of Banu Qainuqa, Banu Nadir and Banu Quraizah.

The earliest Jews that arrived in Medina were from Banu Qainuqa. They were an influential clan. They carry out commercial activities and involved in craftsmanship. They also have strong armed forced. In fact, they have supplied up to 700 armies for the Aws during the Battle of Bu'ath.

Banu An-Nadir was the second largest Jewish community living in Medina. They fled from Palestine because they could not stand the pressure exerted by the Roman army who are Christians. They engage in carpentry, agriculture and trade. They sides with the Aws in the war between the Aus and Khazraj.

Banu Quraizah arrived later in Medina compared to other Jews. They were also known as Darih. They were divided into two clans of Banu Ka’b and Banu Amr. They carry out agricultural activities and their lives were quite luxurious compared to other Jewish clans.

The Jews were highly skilled in their work and life. They imported grains, clothes and alcohol as well as 
exported dates. In addition, they make profit from usury. They loaned properties to Arab’s princes who wanted popularities and praises from poets. The Jews lent their properties and took the Arab's lands as collateral. Usually the Arab's dignitaries were unable to repay the loan so they will mortgage their land to the Jews. The type of loan impose by Jews against Arab’s dignitaries were hard to be amortized that the Arabs had lived in constant hostility because they could not bear the hardship of life.

The Jews at that time were famous for their negative scheme and planning. They incite animosity and hostility between the Arab's tribes who lived near each other. The situation has led the Arab's tribes to be in constant feuds and wars that never end.

\subsubsection{The Muhajirs}

The Muhajirs feel a very noticeable difference when they migrated to Medina. In Mecca, they were oppressed and humiliated. They also do not have any political and economical power there. Their social's relationship with people of Mecca was also blocked by various unjust treaties. Among these unjust treaties were to put barrier for the people of Mecca from having any contact with Banu Hashim and Banu al-Muttalib. Through the treaty, any tribe was not allowed to conduct any transactions, cannot visit, cannot sit together or hang out with any members of Banu Hashim and Banu al-Muttalib. That treaty makes the Muhajirs depressed especially when they cannot get any food supply [1].

However, the Muhajirs faced different situations when they migrated to Medina. In Medina, they were free to do their own thing. They are not dominated by any party. This situation enables them to plan civilization and development agendas. Through the freedom that the Muhajirs gets, they finally united with the Ansar and focused on improving their lives, the economic, the politic and the government. They focus more on the matter of peace and war and completing the matter of halal, haram, worship and moral [1].

\subsection{Uniting the People of Medina}

Major challenge in uniting the people of Medina not only come from the internal problems of hostility among the Aws and Khazraj and the arrogance attitudes of the Jews, but also the challenge of external problems involving the Quraish. The Quraish runs a very great resistance against Muslims although the Muslims have migrated to Medina. The disbelievers had confiscated land, homes and property of the Muslims. They also misuse their political position as the temporal affair's leader and also as the religious leaders who control the affairs of the Kaaba. With their position, they had instigated the unbelievers in the Arabian Peninsula against the people of Medina. The boycott has led Medina to almost paralyze as a result of reduced imports while Muslim immigrants are coming more and more.

Before the emigration, The Prophet has united the nation by bringing together the Ansar and the Muhajirs. Although the Ansar are Muslim, the feelings of racism are still strong among them. The messenger has making them brothers to solve the problem. Moreover, the Prophet had also introduced the Charter of Medina which was a legistative system to be observed by all residents of Madianah at that time. The Charter demand that everything has to be done with trust and everything that should be done are halal and good. This means that the Jews are also required to comply with this law. This situation prevented them from giving out loan with usury which was the main source of their wealth. There are also the possibility of their property will be taken back because the property is acquired through usury from the Arab dignitaries. This situation has caused them to hide their hostility towards the Muslims. This concealed hostility can be seen when the Prophet arrived in Medina by the stories told by Safiyyah bint Huyai bin Akhtab who was the wife of the Prophet Muhammad of Jewish descent. Safiyyahh r.a said; "I was one of the most loved by my father and my uncle Abu Yasir. I've never met them when they're with a child unless they would take me with her. She said: When the Prophet arrived in Medina and stopped at Quba', namely in the village of Bani' Amr bin 'Awf, my father Huyai bin Akhtab went to him with my uncle Abu Yasir bin Akhtab. Early in the morning they were gone but only to return after sunset. Then they returned home tired and lazy while walking shakily. Safiyyah said again, "Then I welcome them as I always do, but for the sake of Allah, no one wants to turn to me as they wear that looks of annoyance. I heard my uncle Abu Yasir said to my father, Huyai bin Akhtab, “Is it him?” My father replied, "I swear by Allah that is the men". Said my uncle, “Are you so sure and confident?” My father replied, "Yes," said my uncle, "So, what goes on in your mind?” My father replied, "By Allah, as long as there is still life in me I'll be his enemy” [2]. 
The Jewish attitude can also be seen in the hadith narrated by al-Bukhari about Islamization of Abdullah bin Salam r.a. Abdullah bin Salam r.a. is a rabbi who was very pious among the Jewish population in Medina at that time. When he knows the arrival of the Prophet to Medina, he soon seek him and ask some questions that the answer will only be known by a prophet only. When listening to the answers given by the Prophet, Abdullah bin Salam embraced Islam. Then Abdullah bin Salam said to the Prophet, "Verily, the Jews are a people who often invent stories. If they know my Islamization before you ask them about me they would accuse of me of something that is not really true". Thereupon the Prophet sent a messenger to invite the Jews. After the Jews came Abdullah bin Salam went into the house. Rasulullah s.a.w him and even asked them, "Who among you man named Abdullah bin Salam?” They answered, "He is the most pious and most powerful worshipper among us. He is also the best people and the child of the best man". There are also reports which stated, "He is our leader and our leader's child". Another story states "The best among us and the son of the best man, the noblest among us and the children of the noblest". Then the Prophet said, "What do you think if Abdullah embraced Islam?" They answered, "We seek refuge in Allah from such" That speech is repeated two or three times. Then Abdullah came out and said, "I testify there is no god but Allah and I testify that Muhammad is the Messenger of Allah". So they answered, "He is a most evil among us and the children of the worst". And they accuse the kibosh on it. In another riwayah of Abdullah bin Salam, he said, "O Jew, fear God. By Allah, no master other than the one, you really know that he is a Prophet and he came up with the truth". So they answered, "You lie".

The internal and external problem that arisen, has makes the Prophet set a strategy to resolve the issue. The internal and external problems were solved by the Prophet by building Mosque of Nabawi (The Prophet's Mosque), introducing Muslims brotherhood and establish the Medina Charter.

\subsubsection{Building the Mosque of Nabawi}

The first step taken by the Prophet after arriving in Medina was to establish the Mosque of Nabawi. Land for building the mosque was purchased from two orphans who owned it. The mosque does not solely serve as a place of worship, but on the contrary it became a meeting place for the Muslims to discuss the affairs of the Medina and outside of Medina. Mosque at that time seemed to be a place for parliamentary debate to reach a decision and perform it. It is also like a meeting place and a reconciliation place for all the races that live in feud before. In addition, the mosque also serves as a residential house for the Muhajirs who were homeless and destitute because they do not have homes, property, wives and children [3].

\subsubsection{Muslims Brotherhood}

Along with the construction of Mosque of Nabawi as a central place to gather, organize and execute all things, the Prophet also making efforts to bring together the Muhajirs and the Ansar at the home of Anas bin Malik. 90 people were involved, half of them consisted of the Muhajirs and the remaining are of the Ansar. They were make brothers on the basis of sharing their life and mutually inherit their property after any of them died. This has been stated in the words of Allah which means:

"And those who have believed and left their homes and striven for the cause of Allah, and those who have given them shelter and help-these indeed are true believers. For them is forgiveness and an honorable provision".

Brotherhood in such a way was to show their love and affection for their Muslim's brother who emigrated from Mecca without their possessions. But the principle of inheritance expires after the Battle of Badr with the word of God:

"And those who believed since then and leave their homes and strove with you, they are of you. In the meantime, people who have blood relations are more entitled to half of the (other) by (law) of Allah; Surely Allah is Knower of all things". 2

The brotherhood was intended to eradicate ignorance racism among the Arabs at that time. Through this system, there is no brotherhood and camaraderie but Islam. Through this system, differences in skin color, descent and citizenship is no longer valid. Thus, one is no longer promoted in rank because of skin color, race, etc. Otherwise someone was promoed due to his dignify way of life and piety [4].

Al-Bukhari [5], narrated when the Muhajirs arrived in Medina, The Prophet has makes Abdul Rahman bin Auf with Sa'ad ibn al-Rabi' brothers. Sa'ad said to Abdul Rahman, "I am the richest person of Ansar, let us part

${ }^{1}$ Surah al-Anfal, verse 74.

${ }^{2}$ Surah al-Anfal, verse 75 . 
my possessions into two. I have two wives, and see which one you like the most, I will divorce her. After I'ddah, then you shall marry her". Abdul Rahman said, "May Allah blessed you, your wife and your possessions for it. Show me where is your market? "Then he was shown to the market of Banu Qaynuqa”. Soon, Abdul Rahman took home the profit from the sale of cheese and fat, the story repeated the next day. Then one day he came with traces of henna on his body. Then the Prophet said, "What is the news?" He answered, "I have been married". He asked, "How much dowry that you give her?" He replied, "One nawah (five dirhams) of gold”.

It was narrated from Abu Hurayrah "People Ansar said to the Prophet" Divide the gardens of palms between us and our brothers. The Prophet replied, "No." Then the Ansar said, "Then let them (the Muhajirs) working in the garden, and we will share the profits with you." They answered, "We hear and we obey".

This event indicates that the Ansar is very concerned about their brothers of Muhajir. From there, can be seen their sacrifice, putting others' need first attitudes, affection and honesty towards brotherhood that exists among them. It also shows the attitude of the Muhajirs who appreciate the generosity of the Ansar. The Muhajirs does not take advantages and do not take profits but only of what they deserve.

\subsubsection{Charter of Medina}

Apart from the brotherhood of Muslims, the Prophet introduces an agreement for the people of Medina. The agreement contains 47 clauses. $23^{\text {rd }}$ first clause discusses the relationship among Muslims, of the Ansar and the Muhajirs. 24 clauses go on to discuss the relationship of Muslims with non-Muslims, namely the Jews. Medina Charter is attached in the Appendix to this article. The phase of the charter in a nutshell is as following;

\section{Political}

1) Prophet Muhammad as a leader in Medina

2) He was also a judge who resolves the problem arising in Medina.

\section{Religion}

1) Medina society is free to practice their religion.

2) They are free to practice their customs as long as they do not conflict with Islamic's legislation.

\section{Social}

1) People of Medina are one community and have a responsibility towards their nation

2) Medina society cannot be hostile to each other.

\section{Legislation}

1) Islamic law applied entirety. However, a nomadic's family rules can be practiced if it’s compatible with Islam.

\section{Economy}

1) Pursuing cooperation between the people of Medina for advancing the national economy.

2) Elements of fraud and usury were abolished in business systems.

\section{Defense}

1) Members of the public are required to maintain Medina from external threats.

\section{Jewish position}

1) Security for non-Muslims (especially Jews) are guaranteed as long as they follow the Charter of Medina.

Briefly, the restructuring of the population in Medina can be seen in Figure 1.

Restructuring of society through the construction of the Prophet's Mosque, Muslim brotherhood and the establishment of the Charter of Medina has builds the foundations of a new society in Medina. Through it, the community united under one legislative mutually agreed.

\section{Population's Restructuring: Malaysia}

Malaysia was previously known by many names. While its lands were consolidated during British colonization during the 18th century until the 20th century it was known as British Malaya. Then, it was called the Malayan Union in 1946. Later the name was changed into the Federation of Malaya in 1948. On September 16, 1963, a larger federation composed of states in peninsular Malaysia with Sabah, Sarawak and Singapore was formed and it was called Malaysia. However, Singapore has decided to no longer be a part of Malaysia on August 9, 1965.

Throughout the history of the formation of Malaysia, the restructuring of the population also occurred after

\footnotetext{
${ }^{3}$ Riwayah hadith from Al-Bukhari, No.125.

${ }^{4}$ Riwayah hadith from Al-Bukhari, No.126.
} 


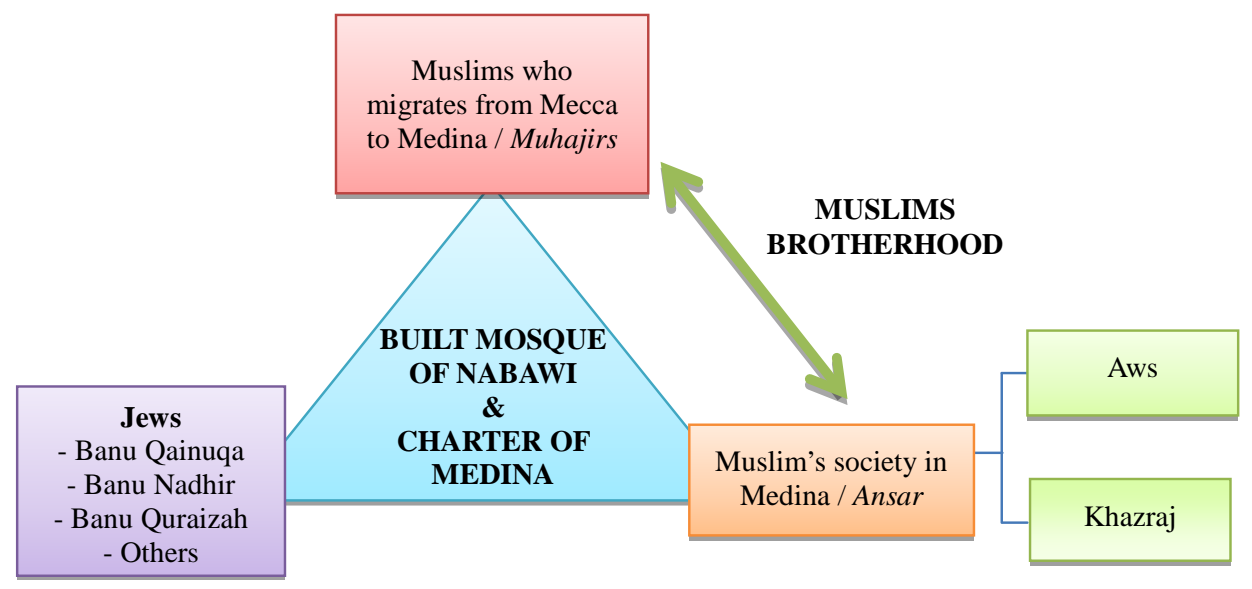

Figure 1. Consolidation of society in medina after the emigration of the prophet Muhammad.

the emigration of the Prophet Muhammad from Mecca to Medina in 622 AD. The same situation also applies to Malaysia on May 13, 1969 that cause bloodshed and loss of property. It's the culmination of the fragility of unity among Malaysians especially among the Malays and Chinese. These events are closely related to the general elections of 1969. The opposition parties comprised of Pan-Malaysian Islamic Party (PAS), Democratic Action Party (DAP), Malaysian People's Movement Party (GERAKAN), People's Progressive Party (PPP) and Malaysian People's Party (PRM). They are said to raise issues involving Nations of Malaysia including the use of national language which is Malay language, the privileges of the Malays as the indigenous and the non-Malays citizenship rights. The opposition parties did not succeed to establish the Federal Government but they managed to prevent the Alliance Party ${ }^{5}$ from obtaining a 2/3 majority of the seats in parliament. Alliance Party at that time comprised of The United Malays National Organisation (UMNO), the Malaysian Chinese Association (MCA) and The Malaysian Indian Congress (MIC) [6].

\subsection{History of Population's Restructures in Malaysia}

Malaysia declared a state of emergency on the evening of May 13, 1969. The declaration resulted in the suspension of the federal Constitution. The situation also means that the Malaysian parliament was suspended and the country then was ruled by the King under martial law. National Operations Council (NOC) was formed following the events. At that point Tuanku Abdul Rahman who was the Prime Minister of Malaysia then, withdrew from leading NOC. He was replaced by the Deputy Prime Minister, Tun Abdul Razak. NOC was established to replace the Malaysian Parliament which had been suspended at the time. NOC's original tasks are:

1) To restore peace and law;

2) To determine the smooth administration in Malaysia;

3) To restore harmony and unity among the races in Malaysia.

NOC also was established to investigate and formulate a new plan so that Malaysia will not repeat the mistakes that have occurred. However, the main goal of NOC was to restore peace in the country so that the multiethnic society of Malaysia can live in harmony again [7]. Based on the report submitted by the NOC (1969), there are many factors that have resulted in the events of May 13, 1969. The factors are:

1) The situation of Malaysia prior to the Second World War;

2) The violence of Malayan Peoples' Anti-Japanese Army (MPAJA);

3) Feelings of worry and suspicion amongst the different races;

4) Racial politics;

5) Triads and politics;

6) The "victory" procession.

\subsubsection{Malaya's Society before Second World War}

British economic policy promotes the incoming of non-Malays immigrants in droves. Labor trafficking occurs

${ }^{5}$ Now known as the Barisan Nasional (BN) or National Front. 
with the inclusion of Chinese and Indians by the British. Later, they continue to reside in Malaya as the country is rich in economic resources such as tin, coal and gold. In addition, generous and tolerant attitude of the Malays towards the immigrants have also been used by the British to continue to bring in immigrants to the Malay Peninsula.

Malay population and the immigrants are administered separately by the British with the policy of divide and rule (Divide and Rule) in Malaysia before independence also has soured the unity among Malaysians. Immigrants from China and India brought into Malaysia to be a labor before the independence of Malaysia. Chinese people were brought in to work at the tin mines. The Indians were brought in by the British to work on rubber plantations. These immigrants were allowed to maintain their identity and were separated from the indigenous population. The indigenous otherwise was excluded from the commercial economic activity created by the British colonialists. However, the indigenous people are comfortable with the situation because they still want to stay with the traditional lifestyle of being a subsistence farmers or fishermen.

This situation has led to the position of British as colonial be stable. During World War II, the Malay people begin to realize that the inclusion of migrants have an adverse effect on the political economy of the Malays. The power of Malay rulers gradually decreased. The spirit of regionalism of Malay's people also has weaken the unity among the Malays. However, after World War II Malays began to realize the situation. They began to demand rights as the natives that have been neglected for so long. The highlight of the claim was the riot on May 13, 1969.

Political awareness among the migrant populations, mainly migrants from China was better than the indigenous population, especially the Malays, who prefers to be on the traditions and customs of their preference. Although, the Chinese in Malaya has political awareness, their political awareness unfortunately contribute more to China during the Revolution of 1911. This heightened awareness makes Kuomintang Organisation in China set up their branches in Malaya in 1912. From there, many branches started to establish until the British had blocked it by banning the organization. However, they are still running through underground movement. In 1923, the Organization of the Kuomintang began to be influenced by communism and the have rapid movement in 1926. In 1927, Chiang Kai Shek act to eliminate communism among the Kuomintang. The elimination have made the extremists communists in Malaya with the help of five representatives of the Communist Party of China arrived in Malaya, to form their own organizations. Such measures have made the development of the Communist Party of Malaya getting stronger in Malaya.

\subsubsection{Violence of Malayan Peoples' Anti-Japanese Army (MPAJA)}

MPAJA was an organization that had received military training from the British. They were assigned to the defense team during the Japanese occupation. They are also a guerrilla force which is also the establishment of the Communist Party of Malaya (CPM), known as the Three Stars have ruled Malaya for 14 days in 1945. Most of its members are Chinese because they have hatred towards the Japanese whom had conquered China then. The hatred was due to the fact that during the conquest of China by the Japanese army, the Japanese killed many people, especially in Nanjing, China. The event is also known as the Slaughter of Nanjing. Although, the Chinese have long settled in Malaysia, their nationalism to China was not eroded.

This situation has led to MPAJA to easily leach into the Malaya community, especially those who are Chinese. When the Japanese surrendered, MPAJA emerged from the woods in July 1945 and do maltreatment to anyone suspected of complicity during the Japanese rule. They took control for three months from the commencement of the Japanese surrender until the British took over the government. It is a distressful period of time not only to the Malays but also the Chinese population residing in Malaya. MPAJA have done injustice by committing torture, murder and extortion against civilians. MPAJA go violence when they managed to rule for 14 days. Any individual who they feel involved in helping Japanese soldiers during the Japanese occupation of Malaya in December 8, 1941 until January 31, 1942 during World War II would be tortured or killed. Violence has been done by the Chinese were sowing resentment in Malaya especially among the Malays against Chinese in Malaya.

\subsubsection{Triads and Politics}

Triad was also a problem that must be faced by the Malay Peninsula. The arrival of the first group of Chinese who migrated from China to Malaya make secret societies began to sprout. The absence of strict laws relating to financial and security has lead the secret societies to take the opportunity to extend their power in certain areas, especially areas inhabited by Chinese ethnic. Their role is expanding that it began to interfere with the political 
affairs of the country. This situation has prompted the British to intervene by holding the Pangkor Treaty which was signed in 1874. However, they continued to disturb the harmony by doing tricks such as 'protection', extortion, kidnapping, robbery and other crimes.

Their activities continue to escalate during the Election 1969, when they interfering with the candidates at the election time. In some areas, it was almost impossible for candidates to campaign without paying "protection money". Coercion and intimidation is the way the triad used to get support in the election. Some of the triad's members deliberately cause chaos to generate tension between races so that the country is becoming weaker.

\subsubsection{Worry and Suspicious}

Fear and suspicion which arose between Chinese and Malays has long been in the history of Malaya. Fights between Chinese and Malays often occur mainly among Chinese gangsters with evil Malay youths. Fear and suspicion was heightened when the Malays did not join the procession to commemorate 100 years of the award of the status of a City to Penang. The Malays do not want to join the march on the grounds that they do not recognize the award rendered by the British government to Penang. Consequently, defamation claiming the Malays will block and disperse the march arisen.

The procession is still held starting at 10:30 am, January 2, 1957 without the Malay participant. Chinese who marched along the parade continues to be warned about the rumor. During their march which was led by police vehicles, police force who heads the march was called separately to investigate a report in a separate place. The police's vehicles moved backward through the parade. The movement of police vehicle in such a way has been misinterpreted by the march's participants. They think that the Malays had attacked marchers on the back. They immediately roll up the parade's banner and some also break the floats to take the sticks and used it as weapons. There are also among the participants who enter houses along the street, and equip themselves with weapons such as butcher knives, axes and others.

The tense situation makes the policemen to immediately disperse the march. Although it had been dispersed, there are about 50 Chinese who participated in the march has taken action to pursue some of the Malays in the homes nearby. A Chinese inspector on duty tried to defend the Malays was also getting injured because his head was struck with axe. He had fired a shot that cause a Chinese died and another one was injured. Following the event, some attacks and small fights have been reported between $2^{\text {nd }}$ until $8^{\text {th }}$ January 1957. During that period, four people were killed and 48 people were injured.

\subsubsection{Racial Politics}

The racial politics began to escalate during Election 1969 when there were election candidates address the issues of racism and the position of the indigenous population in their speeches to garner votes. The following Table 1 also shows the statistics used by the electoral candidates drawn from government records until 1 November 1969.

Following are statistics based on Table 1 that has been altered in a graph, shows the number of employees in government administration is more dominated by non-Malays.

Comparison of these amounts often proclaimed during the election campaign progresses. The Figure 2 show the government sector has been dominated by the non-Malays. This situation indirectly creates suspicion and upsets the Malays when they have noticed their rights was overrided by non-indigenous people.

Table 1. Statistics of government officer according to ethnicity in 1968.

\begin{tabular}{ccccc}
\hline \multirow{2}{*}{ Government Officer } & \multicolumn{2}{c}{ Malay } & \multicolumn{2}{c}{ Non Malay } \\
\cline { 2 - 5 } & Number & Percentage & Number & Percentage \\
\hline Administrative duty & 706 & $57.80 \%$ & 515 & $42.20 \%$ \\
Professional Services $^{*}$ & 385 & $19.20 \%$ & 1,613 & $80.80 \%$ \\
Education Officer & 51 & $29.90 \%$ & 122 & $70.10 \%$ \\
Police & $n . d$ & $38.76 \%$ & $n . d$ & $61.24 \%$ \\
Army & $n . d$ & $64.50 \%$ & $n . d$ & $35.50 \%$ \\
Total & 1142 & $32.26 \%$ & 2252 & $63.74 \%$ \\
\hline
\end{tabular}

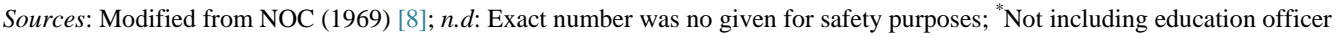




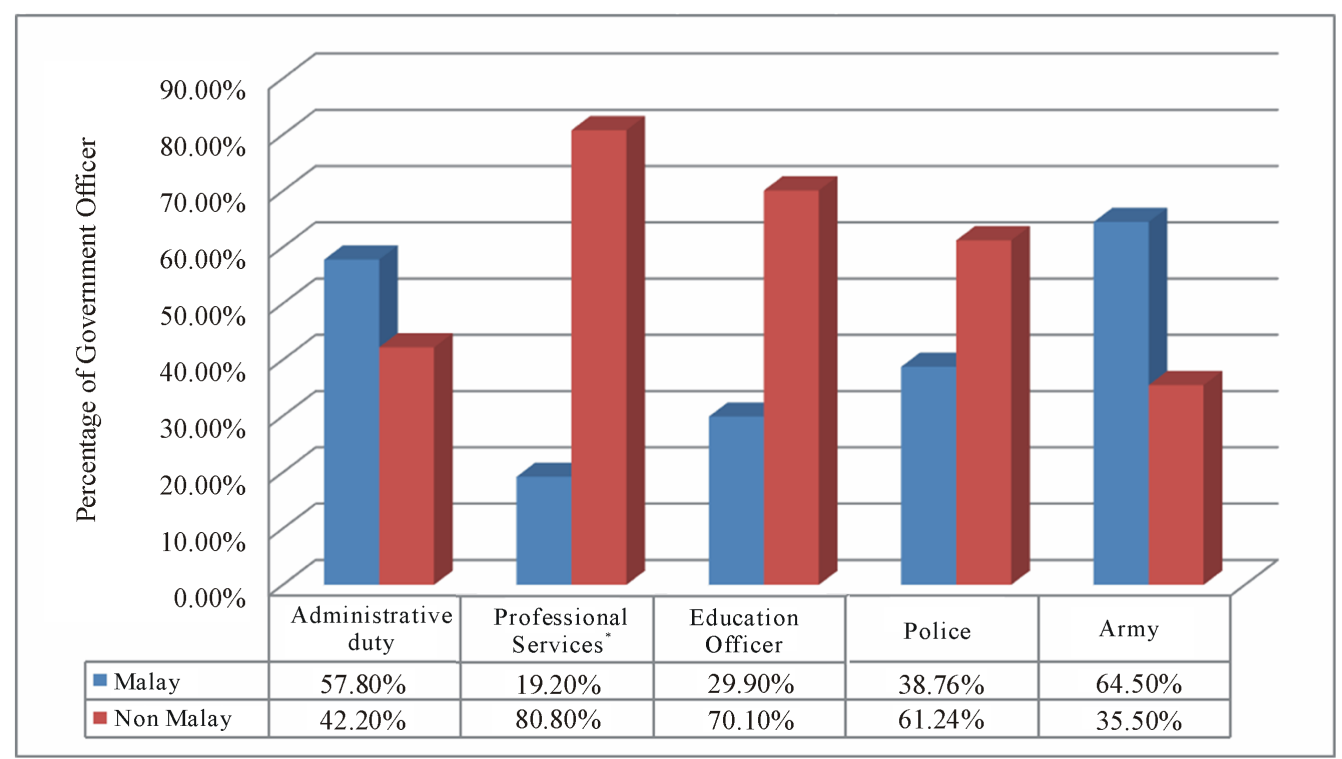

Source: Modified from NOC (1969) [8]; * Not including government officer

Figure 2. Statistics of Government Officer According to Ethnicity in 1968.

The Election 1969's campaign has destroyed the harmony between the races in Malaysia. The issues of rights of indigenous people and poverty among the Malays during the campaign eventually led to bloodshed during the May 13, 1969.

\subsection{6. "Victory" Parade}

Dissatisfaction of the Malays against the non-Malays heightened when the "victory" procession was held by the opposition parties that won seats in the state assembly or parliament. On $11^{\text {th }}$ and $12^{\text {th }}$ May 1969 , the Democratic Action Party (DAP) and Party Movement had organized 'victory' parade. The parade in Kuala Lumpur was filled with incitement and racist taunts. Below were some incidents involving racial abuses during the procession.

1) DAP held a few parades on Sunday, May 11, 1969, all without police permission. At 5:00 pm a procession accompanied by five vehicles and about 15 motorcycles were seen parading through Jalan Brickfields towards Lornie Road. Goh Hock Guan who was the winning candidate for Parliament Bangsar also joined in the parade. When they passed along the Brickfields police station, the participants, the majority of Chinese chanting obscenities and insults like "What the police can do, we're king” and "Remove all Malay's police".

2) At 8:30 pm, DAP that also held a procession through Jalan Bukit Bintang has chided the Malay people who were actually spy on duty. The parade participants have committed lewd acts and shouting vulgar words.

3) At 10:00 pm, another DAP's procession heading towards Kuala Lumpur was reportedly chanted hurtful words like "Dead Malay" and "Sakai went into the forest!" when passing by the Jalan Travers police station.

4) Around 12:00 pm DAP once again held a parade accompanied by Gerakan. When passing through Jalan Brickfields police station they also chanted abusive's words.

5) At 10:00 pm on May 11, 1969, approximately 40 supporters were seen through Jalan Raja Chulan near Pudu Prison along with several cars and scooters. Among the slogans they have championed was "Kuala Lumpur now belongs to Chinese".

4) On May 12, 1969, a parade was held. The difference is that, this parade had permission from the police. The procession was headed by Dr. Tan Chee Khoon who was the candidate that won the election. They go through Jalan Ipoh. They also chanted insulting words like "Go Home Malays", "Malay now no longer has power" and "Now we are in power". They marched with about 500 scooters. When the procession arrived in the Malay area in Kampung Baru, insults like "Malay out, why are they still sitting here?" And "We condemn you, now we are big” issued to the Malays.

7) Around 8:30 pm, a procession both of DAP and Gerakan was held across quarters Bukit Bintang. They also 
shouted vulgar words like "What is this Malays, their states is in our command now".

8) At the same time, a procession also heading to Jalan Pasar Baru, Pudu participate by DAP Gerakan. They yelled the word "Malay Out".

There are many other reports from witnesses explaining about the savagery of the parade's participants celebrating the election victory involving the non-Malays especially by the Chinese. This situation has led the Malays to begin to feel the need for such processions to show that the Malays also have strong support.

On the morning of May 12, 1969, the Honorable Chief Minister, Dato 'Haron stated that UMNO youth of Kampung Baharu UMNO wants to hold a march to highlight the DAP and the Gerakan that they too were not lost in the election. Insults hurled by the Chinese community no longer can make the Malay community to be patience as they used to be Chief Minister, Dato 'Harun agreed to the proposal.

UMNO youth of Kampung Bharu desperately seek as much support for the march. The response is quite impressive. However, Dato 'Harun intends to cancel the march, because he felt something bad will happen during the march. But after being assured by Ahmad Razali, Political Secretary to the Chief Minister of Selangor that they will held a peaceful march, according to rules and that permit from police will also be obtained, have cause Dato 'Harun agree for the parade to be held.

\subsubsection{May 13, 1969's Riot}

After receiving threats, taunts and insults for a few days after the election, there was a group of Malay gathered in Kampung Baru. According to the police report made by Dato 'Harun bin Idris, on the morning of May 13, 1969, members of the State Assembly who have wins in the elections was having meeting at the Office of the Secretary of State, to discuss the establishment of the Selangor state government. When the meeting ended, he went home and he continued to entertain guests who came to congratulate him for winning the election. About 5:00 pm two Chinese people have come to his house and introduced themselves as representatives of Dr. Tan Chan Khoo of Party Gerakan. They stressed that Gerakan would not join the DAP and ask UMNO to form the state government. Dato 'Harun asked the two representatives of the go back and request that Dr. Tan Chee Khoon to call him. Then he received a phone call from David V. who is a member of parliament who won a parliamentary seat in Penang, asking them to form a coalition government. According to him, he was very surprised because it's quite contrary to what were published in local newspapers before the election.

People who want to march had begun to gather in front of the house of Ahmad Razali. Only a few gathered at the home of Dato 'Haron. On the same afternoon, an announcement was made by Party Gerakan stated that the party would remain neutral in the State Assembly. This situation gave way to the Alliance that won the most seats to form a government in Selangor. At the same time, an increasing number of marchers gathered at the residence of the Chief Minister at 7:00 pm on May 13, 1969. However, participants who had gathered there heard rumours that there would be riots by the Chinese in response to the Malay’s procession. The participants take up arms such as knives and machetes to defend themselves if an attack occurs. Some unarmed began to realize the threat that they will receive. This situation makes them immediately make weapons out of bamboo by sharpening the bamboo tips.

Those who were at the residence of the Chief Minister in Kampung Baru, Kuala Lumpur got the news that part of the Malay people who travel to participate in the parade in Kampung Baru was attacked. These statements are based on police reports made by the witness on May 13, 1969. The results of the several police reports that were made concludes that the May 13 incident began when a group of Malays in Kampung Baru on the way to the parade by foot and riding scooter have been abused by a group of Chinese and Indians in Setapak, Kuala Lumpur They had to walk and ride a scooter around $26.6 \mathrm{~km}$ for the bus service has been stopped due to the conflict. The results of the incident were severe fighting between the two sides. They were throwing rocks and bottles. Then chaos is spreading to Kampung Baru, Kuala Lumpur only within about ten to 15 minutes. The news on the brawl that began in Setapak has sparked a brawl at Kampung Baru and the surrounding areas. These fights resulted in many people were injured and killed. Property such as homes and vehicles were also destroyed and burned. Table 2 shows statistic of death, injury and destruction that took place so far received by the government in connection with the riots. According to a report on the riots, the figures shown above are based on the report as of July 31, 1969. However, the actual number is unknown because, according to witnesses during the incident, the amount is more than the statements recorded.

Riot and state of emergency that happened in 1969 has prompted the Malaysian government to promulgate 
Table 2. Number of death, injury, capture and charges during the period of May $13^{\text {th }} 1969$ riot.

\begin{tabular}{cccccc}
\hline Categories & Malay & Chinese & Indian & Others & Total \\
\hline Death according to ethnicity & 25 & 143 & 13 & 15 & 196 \\
Injury by firearm & 2 & 125 & 17 & 1 & 145 \\
Injury by other weapon & 90 & 145 & 9 & 15 & 259 \\
Captured & 2077 & 5126 & 1874 & 66 & 9143 \\
Charges in court for not abiding the curfew & 1133 & 2907 & 1470 & 51 & 5561 \\
Charges on manslaughter and burning & 40 & 5 & 0 & 0 & 45 \\
Total & 3367 & 8451 & 3383 & 148 & 15,349 \\
\hline
\end{tabular}

Source: Modified from NOC (1969) [8].

the 1971 New Economic Policy (NEP) to address the problem so that it will not recur. Starting with the DEB and so on until now, the policies enacted by the government aimed at creating racial integration in Malaysia so that the incident is not repeated. Restructuring race is the first step made by the government to create racial integration in Malaysia until today.

\subsection{Population Restructuring of Malaysia}

NOC which was established to redesign a new plan to address the May 13 incident Malaysia has submitted the National Principles or Pillars of the Country which has five principles. The five principles are:

1) Belief in God;

2) Loyalty to King and Country;

3) Supremacy of the Constitution;

4) Rules of Law;

5) Courtesy and Morality.

\subsubsection{Belief in God}

Nation of Malaysia established on the basis of belief in God. Based on that belief, it makes Malaysia a sovereign nation and country. Federal Constitution provides that Islam is the official religion. However, other religion and belief can be practiced in peace within the Federation. Action which discriminates against any citizens on the grounds of religion is prohibited. The National Principles's Committee, NOC aware of the importance of religion and belief in God in human life. The absence of religion may undermine an individual's personality and also a nation. Recognizing the importance of it makes this principles was placed as the first principle of the National Principle.

\subsubsection{Loyalty to King and Country}

Loyalty to King and Country means every citizen shall devote his full loyalty to the king who ruled the country where they reside without reducing allegiance to His Majesty the Supreme Lord of the Federation (Yang diPertuan Agong). Parliamentary Democracy and Constitutional Monarchy with His Majesty the Yang di-Pertuan Agong as the Supreme Head of State is the practice in Malaysia. In line with the position of the Yang di-Pertuan Agong as king by the constitution, the monarchy is also practiced in every state and as for states that do not have kings, the governors (Yang di-Pertua Negeri) will be the head of state. Moreover, His Majesty, the Kings and the Governors are the symbol of unity of the people.

\subsubsection{Supremacy of the Constitution}

The next principle is emphasized on the need for people to accept, obey and defend the Constitution of the State because it is the highest source of legislation. It serves to provide protection to all citizens of this country of their rights and privileges as citizens. Every citizen must respect, appreciate, and understand the meaning and content as well as the historical background of the establishment of the State Constitution. The National Constitution was drafted based on the agreement of all races in Malaysia. It is the people's social contract that cannot be questioned and threatened by any individual or any party. 


\subsubsection{Rules of Law}

Justice is founded on the rule of law as all citizens are treated equally before the law of the country. Fundamental freedoms guaranteed to all citizens of Malaysia. Law based on the Constitution. The rule of law must be accepted and defended by citizens. It is guaranteed by an independent and competent judiciary. Through it, the rights of all citizens can be practiced freely as long as it does not violate the law and matters as guaranteed by the Constitution of the State. The rights of freedoms guaranteed by the Constitution are not includes the right to overthrow the government at all with violence or in ways that are not in accordance with the Constitution.

\subsubsection{Courtesy and Morality}

This last principle emphasizes the development of a personality and behavior of the people. The aim is to establish citizens who are courteous and have good morals. Individual who are polite and have good morals are the most meaningful and important in the context of relationships with each other in various communities in the country. These principles serve as a guide so that people's behavior is being maintained and developed in accordance with the personality of the people and values.

Besides Pillars, the New Economic Policy (NEP) was also enacted for the purpose. Race riots that occurred on May 13, 1969 gave a great lesson to the government and people of Malaysia that they have to unite. Government policies enacted since then, often puts people unification as the policy's main agenda. Starting with the NEP, which is a socio-economic program launched by the second Prime Minister of Malaysia, Tun Abdul Razak bin Hussein who recently appointed in 1970 to replace the Tunku Abdul Rahman Putra Al-Haj.

NEP aimed at achieving national unity and national integration. It is designed to achieve two objectives, namely:

1) Reduce and eradicate poverty by increasing income and employment opportunities for all Malaysians regardless of race; and

2) Accelerate the process of restructuring Malaysian society to correct the economic imbalances so as to reduce and eventually eliminate the identification of race based economic function.

NEP is a policy launched by the government in 1971 through the Second Malaysia Plan. Its objective is to restructure the socio-economic imbalances that exist in Malaysia. After the tragedy of May 13, the government began to realize that a balance distribution of economic is importance for the nation to be balanced and united. They also take account of the poverty and the inability of some races to compete with other races.

Tension occurs primarily between Malay and Chinese stems from issues of poverty and indigenous rights. After Election 1969, the Malays began to realize that they are poor compared to other races. They also lag and less able to compete against other races even if the economy is experiencing good growth after independence.

\section{Population's Restructuring and the Impact on Poverty}

The event in Madinah and Malaysia, as discussed earlier was very similar. Unrest, war, abuse and riots occurred due to lack of understanding and solidarity between the citizens. Dissatisfaction arising between the races has triggered the disaster. This situation has led to drastic steps has been taken by the Prophet Muhammad s.a.w, as a chairman of the government in Medina to prevent the problem from recurring. The drastic measure also has been taken by the Malaysian government. Drastic measure was necessary to ensure the country to recover by restoring the political, economic and social development to the existing situation or better than before the conflict. The drastic measures have been taken by the Messenger of Allah upon arriving in Madinah were, as discussed previously, namely by building Mosque of Nabawi, introducing the concept of Muslims brotherhood and establishing the Constitution of medina or Charter of Medina.

In Malaysia, before 1969, even though Malaysia has gained its independence on August 31 ${ }^{\text {st }}$, 1957, racial conflicts always arise. The situation worsened after the 1969 general election until the tragedy of May $13^{\text {th }}$. The main cause of the tragedy was dissatisfaction among indigenous people, especially among the Malays, when their rights and privileges began to be confiscated and challenged by non-indigenous people.

Restructuring of the population that occurred in Malaysia has caused a big impact on the economic development of the people of Malaysia today. According to the Economic Planning Unit, Department of Statistics Malaysia, Malaysia has managed to reduce its poverty rate from $49.3 \%$ in 1970, before the NEP was launched to $1.7 \%$ after 44 years of the NEP was launched. Poverty among indigenous and other ethnic were declined. Table 3 shows the changes that occurred in greater detail before and after NEP was launched.

Based on textual analysis that has been done, it turns out the restructuring of the population not only 
Table 3. Incidence of poverty according to ethnicity and strata, 1970 and 2012 (\%).

\begin{tabular}{ccc}
\hline Year & $\mathbf{1 9 7 0}$ & $\mathbf{2 0 1 2}$ \\
\hline Malaysia & 49.3 & 1.7 \\
Indigenous & 64.8 & 2.2 \\
Chinese & 26.0 & 0.3 \\
India & 39.2 & 1.8 \\
Others & 44.8 & 1.5 \\
Strata & & \\
Urban & 21.3 & 1.0 \\
Rural & 58.7 & 3.4 \\
\hline
\end{tabular}

Source: Modified from Economic Planning Unit, Malaysia, 2014 [9].

succeeded in achieving unity and developing a nation, but it could be the best example to eradicate poverty, especially to a multiracial country in a short period of time. Restructuring of the population has corrected socioeconomic imbalances that exist between races in Malaysia and in the different regions. There were five cases have been outlined for the purpose. First, by modernizing the rural areas. Second, by reducing the imbalances in the structure of employment. Third, by giving faster ownership for Malaysians in the capital and stock ownership of a company. Fourth, by establishing a commercial and industrial community among the Malays and natives. Fifth, by developing the states and areas that were undeveloped.

Based on the studies that have been conducted on the two situations that occurred during the restructuring of population either in Madinah or even in Malaysia, there were some common elements in the restructuring of the population in both places. The elements were the religion, life, intellect, lineage and property. These five elements were actually the elements that contained in the Maqasid Shari'ah [10]. Maqasid Shari'ah has been submitted by al-Syatibi [11], which aims to create a good (manafaah) and reject evil and to eliminate the harm (mafsadah) [12]. In addition, maqasid also can defined the objectives to be achieved in implementing something based on guidelines set by the legislation in implementing the law [13].

\subsection{Element of Religion}

Based on restructuring situations that occur in Madinah and Malaysia, the religious element was the core of the restructuring of its population. This element was clearly included in Madinah when the Prophet SAW initiates Muslim brotherhood, ordered the Prophet's Mosque construction and establishes the Medina Charter.

Religious elements were present during the unity of the fellow Muslims living in Medina, because through religion, they unite regardless of tribe, race, color, language or appearance. Through this brotherhood they know each other, help each other and sacrifice for each other. Construction of Mosque of Nabawi also closely associated with religious elements. Mosque at that time not only serves as a place of worship but also as a place to organize and plan administrative agenda that were closely linked with the economic, political and social matters. Medina Charter also still relates to religious element which was the freedom to practice any religion in Medina. Freedom of religion is clearly contained in Article 2 to Article 12 and Article 30 to Article 40 [14].

In Malaysia too, still adopt religious element in efforts to restructure its society. Elements of this reorganization can be clearly seen in the first principles of the National Principles, which was Belief in God. Through the National Principles, Islam is the official religion of Malaysia as enshrined in the Malaysian Constitution in Articles 3 and 5. But, like the Charter of Medina, Malaysia also allows for freedom of religion in the country.

\subsection{Element of Life}

Life here means the right of a person to feel safe. Security issues were also at the core of the restructuring of society in Medina and Malaysia. Before the restructuring was done, war and racial strife always happened. However, with the Charter of Medina and Pillars, public safety in Madinah and Malaysia began to be assured. In the Charter of Medina, it was noted that they have to defend Medina from the enemy attacked as stated in Articles 41, 43, 44 and 45. In addition, the community of Medina cannot be hostile to each other. These elements were contained in Articles 14 to Article 17 of the Charter of Medina. In Malaysia, too, it is clearly mentioned in the constitution which was also one of the principles in the National Principles. That Constitution meant was in 
Article 5 which describes the personal liberty of citizens. In Act 5 (1) describes the security and safety of its citizens' lives can never be arbitrarily deprived except in accordance with the law [15].

\subsection{Element of Intellect}

Element of intellect should also be emphasized in order to restructure society. Among the elements of intellect includes the right to voice opinions. Restructuring of the population in Medina also produces these elements in the system for restructuring the inhabitants. People were allowed to discuss and express their opinions to the administrator. It was contained in Articles 24 and 52. In both of these articles, they were allowed to express their opinions. However it should be according to al-Qur'an and Hadith. In Malaysia too, restructuring of population also using sense element in their efforts to restore peace and in turn to reconstitute racial inequality that occurred. NEP which was formed after the May $13^{\text {th }}$ tragedy was meant so that all people were treated equally to avoid dissatisfaction among the different races.

It also stated in the Constitution of Malaysia, Article 5 up to Article 12. All of the acts were provided for citizens to have personal freedom, the freedom to choose work, the freedom to express their views, freedom of religion and freedom of the road for the study. All of these things have to do with the human mind that Allah Almighty bestowed symbolizing man's freedom to choose.

\subsection{Element of Lineage}

Restructuring of society should also contain elements of care for the lineage. It also indicates the right to keep the races should be properly maintained. This can be seen in Madinah when the Prophet mentions every tribe in Medina, one by one in the Medina Charter document. Among the tribes was the Banu Awf, Banu al-Hars, Banu Sa'idah, Banu al-Najjar, the Jewish of Banu Najjar, the Jewish of Bani al-'Aws and Jewish of Banu Tsalabah. In addition, it also shows respect given by the Prophet against any tribe in Medina. It also shows that Islam does not prevent people from loving its linage.

Article 153 of the Constitution of Malaysia has also allocated the Yang di-Pertuan Agong to maintain the privileges of the Malays and the natives of Malaysia referred to as natives. They are protected under the article with the existence of a quota entry in the public service, scholarships and public education. It is also known as a social contract between the people of Malaysia during independence through Article 14 to Article 18 in respect of the granting of Malaysian citizenship to people of non-Malays. Although this privilege were enjoyed by the Malays, but the non-Malays in Malaysia has never been suppressed.

\subsection{Element of Property}

The right to own property also cannot be denied in a country that wants to restructure its society. This right is also important because through it, poverty eradication can be done well. As in the Constitution of Medina, property ownership by the people of Medina was done fairly by eliminating usury loans as practiced by the Jews before the coming of Prophet Muhammad to Medina [1].

In Malaysia, possession of property also was allowed as enshrined in the Federal Constitution, Part II, Human Rights, Article 13, which states clearly on the right to property. Pursuant to Article 13 (1), no person should be deprived of property except in accordance with the laws of Malaysia. Pursuant to Article 13 (2), it also explained that no law may provide for the acquisition or use of property forcibly without adequate compensation. Through Article 11 (3c) also explains that the acquisition or possession of property and hold and administer of the property according to the law also was allowed to the religious groups in Malaysia. However, the government also has the power to acquire, hold and dispose of any kind of property or enter into contracts of any property pursuant to Article 69 (1). But it is also based on the contacts have been made at the suit [15].

\section{Conclusion}

Restructuring of society is very important especially in a country that has a pluralistic society. Restructuring of society gives space to the people in a country to get equal rights, particularly the matter of in acquiring properties. It is also a strategy to eradicate poverty in a country irrespective of race, colour, descent or appearance. By recognizing the social and economic imbalances that occurred either in Medina or in Malaysia, the government has sought to re-unite the society by reducing the gap in economic, social, cultural, placement and so on. 


\section{References}

[1] Al-Mubarakfuri, S.R. (2011) Sirah Nabawiyyah S.A.W. Yayasan Dakwah Islamiah Malaysia, Kuala Lumpur.

[2] Ibn Hisham, A.M.A.M. (2009) Sirah Nabawiyyah Ibnu Hisham, Vol. 1 (Translation, As-Sirah An-Nabawiyah li Ibni Hisyam). Al-Hidayah Publications, Kuala Lumpur.

[3] Umar, A.M., et al. (n.d) Mukjam al-Arabi al-Asasi. Saudi ‘Arabiyyah: Jamiah al-Duwal al-Arabiyyah: al-Munazzamah al-Arabiyyah li al-Tarbiyyah wa al-Thaqafah wa al-Ulum.

[4] Kamsari, S.A. (2010) "Penyatuan Muhajirin dan Ansar” in Utusan Online. http://ww1.utusan.com.my/utusan/info.asp?y=2010\&dt=1013\&sec=Bicara_Agama\&pg=ba_01.htm

[5] Al-Bukhari (n.d). Shahih Bukhari, Volume 4, Book 55. In: Shahih Bukhari. http://www.sahih-bukhari.com/Pages/Bukhari_4_55.php

[6] Wariya, C. (2004) Abdullah Ahmad Badawi: Perjalanan Politik PM ke-5. Utusan Publications, Kuala Lumpur.

[7] Pandian, S. (2006) Abdullah Ahmad Badawi: Jalan ke Puncak. Utusan Publications \& Distributors Sdn. Bhd, Kuala Lumpur.

[8] NOC, Nation Operations Council (1969) The May 13 Tragedy. Nation Operations Council, Kuala Lumpur.

[9] EPU, Economic Planning Unit, Malaysia (2014) "Table 6: Incidence of Poverty by Ethnicity, Strata and State, Malaysia, 1970-2012” in Unit Perancangan Ekonomi, Jabtan Perdana Menteri. http://www.epu.gov.my/documents/10124/669145a4-1b34-4f04-9043-31b24d1c3442

[10] al-Khadimi, N.M. (1998) Al-Ijtihad al-Maqasidi. Qatar.

[11] Al-Syatibi (1996) Al-Muwafaqat Fi Usul al-Syariah, Vol. 2. Dar al-Ma’rifah, Beirut.

[12] Al-Izz bin Abdul Salam (n.d) Qawaid al-Ahkam fi Masalih al-Anam. Dar al-Ma’rifah, Beirut.

[13] al-Raisuni, A. (1992) Nazariyyat al-Maqasid I’nda al-Imam al-Syatibi. Beirut, al-Maahad al-Alami li al-Fikr al-Islami.

[14] Tahir-Ul-Qadri, M. (2012) The Constitution of Madina: 63 Constitutional Articles. Minhaj-ul-Quran Publications, London.

[15] Perlembagaan Persekutuan (2009) “Undang-undang Malaysia: Perlembagaan Persekutuan” in Portal Rasmi Jabatan Ketua Pengarah Tanah dan Galian Persekutuan.

http://www.kptg.gov.my/sites/default/files/article/perlembagaanpersekutuan.pdf 